\title{
Communicative theatre space in the linguistic and pragmatic paradigm
}

\section{[Коммуникативное пространство театра в лингвопрагматической парадигме]}

\author{
Marina R. Zheltukhina - Larissa G. Vikulova - \\ Svetlana V. Mikhaylova - Liudmila A. Borbotko - Alfiya R. Masalimova
}

DOI: 10.18355/XL.2017.10.02.08

\begin{abstract}
Аннотация
В данной статье коммуникативное пространство рассматривается в системе ключевых понятий и таких категорий лингвопрагматики, как адресант, адресат, речевое поведение, коммуникативная стратегия. Выделена сфера коммуникативного пространства театра, значимая для процесса речевого взаимодействия адресанта и адресата. Определена роль метатекстовых вставок в текстовое пространство пьесы как одного из инструментов формирования коммуникативного пространства.
\end{abstract}

Ключевые слова: лингвопрагматика, коммуникативное пространство, сфера коммуникативного пространства театра, коммуникативно-прагматические типы речевого поведения

\section{Введение}

Театральный дискурс характеризуется как лингвистическими, так и экстралингвистическими факторами, поскольку представляет собой результат человеческой деятельности в контексте (социальном, событийном, ценностном). Исследование театрального дискурса как одной из форм художественного дискурса осуществляется в научных работах с позиций литературоведения, когнитивной лингвистики, теории коммуникации, лингвокультурологии, семиотики, искусствоведения, театроведения. Труды по обозначенной проблематике сами по себе являются ценными, однако в силу других задач они не рассматривают авторский метатекст пьес с позиций театрального дискурса. Предметная область «театр» входит в социокультурный и языковой контекст общества, одной из основных особенностей которого является исторически и культурологически сформировавшаяся сложность коммуникативной ситуации, в рамках которой реализуется процесс аккультурации зрительской аудитории. В этой связи представляется необходимым обратиться к изучению социально ориентированного театрального дискурса как креативного коммуникативного пространства и моделированию его параметров, позволяющих выявить процессы диалогового взаимодействия актеров и зрителей (Borbot'ko, 2015; 2017).

Актуальность данной проблемы обусловлена развитием теории дискурса как одной из перспективных областей лингвистической науки, изучающей дискурсивную природу текстов различного жанра. Актуальность объясняется также усилением внимания современной лингвистики к социальной, культурологической и аксиологической интерпретации дискурсивных образований, а также моделированию жанров конкретного дискурса, исходя из его соотнесенности с другими видами дискурса, 
составляющими целостное коммуникативное пространство социума.

В качестве рабочей гипотезы выдвигается положение о том, что театральный дискурс обладает свойствами коммуникативного пространства, в рамках которого осуществляется опосредованное общение автора пьесы и зрителя в зале, где медиатором выступают режиссер-постановщик и актеры, играющие на сцене. Этот вид дискурса имеет целью максимальное воздействие на потенциального адресата (зрителя).

Социальные процессы рождают свое коммуникативное пространство, в рамках которого реализуются коммуникативные дискурсы (социальный процесс, включающий текст в различных аспектах). Коммуникативное пространство структурировано первичными и вторичными коммуникативными процессами. Первичные процессы поставляют информацию, а во вторичных процессах происходит ее обсуждение и распространение. Успешность первичного коммуникативного процесса зависит от продолжения его во вторичных процессах (Avseenko, Duhvalova, Naumova, 2001; Zheltuhina, 2003). Основная характеристика коммуникативной стороны театрального общения - eе знаковый и интерпретативный характер. Информация всегда облекается в форму каких-либо знаков, иначе она не может быть представлена человека. Поскольку точного соответствия между различными знаковыми системами не существует, перевод из одной знаковой формы или системы кодирования в другую всегда предполагает переформулирование, или интерпретацию (Zheltuhina, 2003).

Театральный дискурс в силу собственных специфических
особенностей реализуется через ряд категориальных признаков (институциональность, репертуарность, знаковость, синтетичность, ритуализованность, регламентированность и конвенциональность, сценичность, театральность, развлекательность), определяющих его конститутивные признаки. Канвой театрального представления являются авторские метатекстовые вставки, которые можно рассматривать как ориентирующую систему: она предполагает фокусирование на актуальной для содержания информации, идентификационное (опознавательное) ориентирование (в терминологии С.Л. Васильева), ценностное ориентирование, ориентирование в пространстве и времени (хронотоп пьесы).

\section{Теоретическая база исследования: состояние изученности проблемы}

Как показывают теоретические работы последних лет, лингвисты активно вводят термин «коммуникативное пространство» в научный обиход. Принимая в расчет специфику театрального дискурса, понимаемого как социальное действие, воплощенное театральной труппой под руководством режиссера-постановщика перед зрительской аудиторией, необходимо рассмотреть театральный дискурс с позиции его социокультурной и прагматической обусловленности. Подобный подход позволяет говорить о существовании специфического коммуникативного пространства театрального дискурса.

Обратимся к термину коммуникативное пространство для определения его основных характеристик. В толковании известного лингвиста и литературоведа Б.М. Гаспарова (Gasparov, 1996: 223), коммуникативное пространство представляет собой особую мысленную сферу, «в которой говорящий субъект ощущает себя всякий раз в процессе языковой деятельности 
и в которой для него укоренен продукт этой деятельности». Основными характеристиками коммуникативного пространства ученый считает его изменчивость, динамичность, дисконтинуальный (неравномерный) характер. Согласимся с авторитетным специалистом в том, что коммуникативное пространство в совокупности и взаимодействии всех своих аспектов «образует целостную коммуникативную среду, в которую говорящие как бы погружаются в процессе коммуникативной деятельности» (Gasparov, 1996: 225). Эта целостная коммуникативная среда, определяемая метафорой коммуникативное пространство, включает в себя жанровую характеристику конкретного вида деятельности, предметное содержание, общую интеллектуальную сферу, определяемую принадлежностью содержания, а также коммуникативную ситуацию.

Интерес представляет определение коммуникативного пространства, предложенное известным специалистом в области коммуникативных технологий Г.Г. Почепцовым, который склонен трактовать его, прежде всего, как информационное с оговоркой: «в случае коммуникации речь уже идет о двустороннем процессе, где и генератор, и получатель информации обладают активными, формирующими эту коммуникацию ролями» (Pochepcov, 2001: 295296). Это справедливо по отношению к театральному дискурсу, поскольку коммуникативная ситуация, развивающаяся в рамках данного пространства, обязательно двусторонняя. При этом роли коммуникантов четко определены до начала коммуникации.

Коммуникация в рамках пространства театрального дискурса понимается в данной работе как двухвекторный процесс, в ходе которого, с одной стороны, осуществляется передача информационного сообщения адресантом, а с другой - происходят восприятие и переработка получаемой информации адресатом. Реакция адресата (театральной публики) на то или иное получаемое сообщение позволяет предположить, что его роль в процессе формирования театральной коммуникации также является активной.

Опираясь на представления Б.М. Гаспарова и Г.Г. Почепцова о коммуникативном пространстве, лингвист Т.А. Воронцова, занимающаяся лингвопрагматическим исследованием коммуникативного (коммуникативнопрагматического) пространства, определяет последнее как «речевую ситуацию, включающую роли говорящего и слушающего, характеристики времени и места, правила согласования этих целей в рамках кооперативного принципа, правила передачи роли говорящего от одного коммуниканта другому и т.п.» (Voroncova, 2009: 13). Полагаем, что аспекты коммуникативного пространства, обозначенные в данном определении, относятся и к театральному дискурсу, где четко разграничиваются роли адресанта, передающего информацию, и адресата, воспринимающего сообщения адресанта, а также наличие хронотопических характеристик, без которых невозможно поставить спектакль на сцене. Хронотоп, который определяет, как правило, драматург, представлен в текстовом поле пьес в виде авторских ремарок - особых указаний для режиссера-постановщика и актеров.

В то же время коммуникативное пространство, по мнению Т.А. Воронцовой, включает в себя речевую, аксиологическую и когнитивную сферы. Речевая сфера предполагает наличие определенных дискурсивных конвенций правил, регламентирующих речевое участие в процессе коммуникации каждого из коммуникантов. Границы обозначенной речевой сферы определяются правилами коммуникации в конкретном дискурсе и параметрами конкретной 
речевой ситуации (Voroncova, 2009: 14).

Вместе с тем аксиологическая сфера коммуникативного пространства в рамках театрального дискурса реализуется в соответствии с ценностными установками драматурга, режиссера-постановщика и актеров. Она адресована зрительской аудитории, которая воспринимает и оценивает происходящее, также основываясь на собственной системе ценностей.

Т.А. Воронцова приходит к важному выводу, что адресант, передавая сообщение адресату в рамках коммуникативного пространства, склонен ориентироваться на одну из трех установок:

1) вторгнуться в коммуникативное пространство адресата, трансформировать это пространство в соответствии с собственной картиной мира, идеями, системой ценностей и оценок;

2) сделать эксплицитными собственные представления и ценности, не стремясь при этом существенно изменить представления и оценки адресата;

3) создать общее с адресатом коммуникативное пространство, качественно новое - как для адресата, так и для адресанта (Voroncova, 2009: 16).

Следует отметить, что все три установки актуальны для театрального дискурса, поскольку адресант ставит цель воздействовать на взгляды адресата (зрителя), что впоследствии повлечет за собой формирование общего для адресанта и адресата коммуникативного пространства. Только в этом случае возможен успех спектакля у публики.

\section{Методологические основы и методы исследования}

Антропоцентризм как методологический принцип определил направление работы - от изучения конкретного языкового материала, представляющего театральный дискурс в аспектах его порождения (позиция адресанта), понимания (позиция адресата) и воздействия на адресата, к выводам, касающимся осмысления образа homo ludens (J. Hyojzinga) в рамках театральной коммуникации. Принцип нарративности (O.A. Radchenko), способствующий осмыслению критериев объективности в научном описании объекта исследования и позволяющий опираться на персонифицированные идеи, гипотезы и термины, выдвигаемые специалистами в сфере театрального дискурса, выступает как один из приемов исследования.

Данная работа представляет собой междисциплинарное исследование не только авторского текста, но и авторского метатекста как ориентирующей системы при моделировании коммуникативного пространства театра. Комплексный подход к анализу обозначенных лингвокультурологических феноменов базируется на идеях и методах прагмалингвистики, социолингвистики, лингвокультурологии, эстетики и искусствоведения (Pochepcov, 2001; Voroncova, 2009; Karasik, 2013; Vikulova, Serebrennikova, 2014; Borbot'ko, 2015; Zheltukhina, Krasavsky, Ponomarenko, Aleshchanova \& Pavlov, 2016; Zheltukhina, Slyshkin, Ponomarenko, Busygina \& Omelchenko, 2016; Zheltukhina, Vikulova, Serebrennikova, Gerasimova \& Borbotko, 2016; Zheltukhina, Vikulova, Slyshkin \& Vasileva, 2016; Zheltukhina, Zinkovskaya, Katermina \& Shershneva, 2016; Zheltukhina, Mouzykant, Barabash, Ponomarenko, Morozova, Mori, 2017, etc.). Языковой анализ дискурсивных признаков авторского метатекста в театральном дискурсе опирается на коммуникативные принципы прагмалингвистики, с учетом социокультурных характеристик контекста, а также лингвокультурологических особенностей коммуникативного пространства театрального дискурса. 
Для решения поставленных задач, состоящих в рассмотрении коммуникативного пространства в системе ключевых понятий и таких категорий лингвопрагматики, как адресант, адресат, коммуникативная стратегия; выделении сферы коммуникативного пространства театра, значимой для процесса речевого взаимодействия адресанта и адресата; определению роли метатекстовых вставок в текстовое пространство пьесы как одного из инструментов формирования коммуникативного пространства, с учетом специфики исследуемого материала, ведущим методом исследования был выбран общенаучный описательный метод, включающий в себя основные компоненты: наблюдение, обобщение, интерпретацию, классификацию. В ходе исследования применены лингвистические методы дискурс-анализа, семиотического анализа, формализованные приемы представления результатов (схема).

\section{Результаты и дискуссия}

Вслед за Б.М. Гаспаровым (Gasparov, 1996: 222), заметим, что создание коммуникативного сообщения, осуществляемое драматургом, режиссеромпостановщиком и театральной труппой, а также его интерпретация зрительской аудиторией невозможны без определения среды принадлежности данного сообщения. Как подчеркивает Б.М. Гаспаров, представление автора сообщения о реальном или потенциальном адресате, его убеждениях, интересах и намерениях играет значительную роль в формировании коммуникативного пространства (Gasparov, 1996: 223). В театральном дискурсе изначальным автором сообщения (адресантом) является драматург. Первым из адресатов становится режиссер-постановщик, который ретранслирует информационное сообщение театральной труппе, которая, в свою очередь, «доставляет» его зрителю.

Добавим, что прогнозирование потенциального адресата (зрительской аудитории) адресантом (драматургом, режиссером-постановщиком и актерами) обеспечивает успех избранной коммуникативной стратегии.

В свою очередь С.Н. Плотникова говорит о необходимости разграничения языкового, дискурсивного и коммуникативного пространств, основываясь на определении языковой, дискурсивной и коммуникативной личности соответственно (Plotnikova, 2008). Для настоящего исследования актуально определение коммуникативного пространства, предложенное этим автором. При формировании сообщения дискурсивная личность (в данном случае - драматург) отдает себе отчет в том, кто является адресатом сообщения. Следовательно, происходит трансформация автора в коммуникативную личность, погруженную в коммуникативное пространство. Адресат сообщения - зритель - также является коммуникативной личностью. В процессе коммуникации между адресатом и адресантом осуществляется непосредственный обмен информацией, если коммуниканты находятся в одном физическом пространстве (реплики персонажей, произносимые со сцены одобрительная или неодобрительная реакция зрительного зала в виде аплодисментов или свиста соответственно), и опосредованный обмен (радиоспектакли и телепостановки).

Определение пространства в трактовке С.Н. Плотниковой подразумевает «пространство живых людей» (Plotnikova, 2008: 134). Пребывание личности в коммуникативном пространстве обусловлено способностью производить такие дискурсы, которые будут востребованы 
другими участниками данного пространства. Главенствующую роль имеют проговариваемые дискурсивные смыслы. Если один из коммуникантов выражает ложные дискурсивные смыслы, а также если передаваемые смыслы непонятны или не значимы для других участников коммуникации, это может привести к выходу коммуникантов из данного коммуникативного пространства, например, в театре - уход из зала, клакерство и т.п.

Современная теория коммуникации определяет понятие свободы слова как дискурсивную и коммуникативную свободу, когда индивид способен свободно формировать дискурсы, а также реагировать на них вне зависимости от своего социального статуса. Однако при рассмотрении театрального дискурса важно отметить, что коммуникативная свобода, например, театрального коллектива, возможна только при наличии определенных рамок, установленных цензурой. Цензура как один из аспектов институциональности театрального дискурса предполагает, что дискурсы, формируемые и воспроизводимые на театральной сцене, обусловлены социальными нормами и в некоторых случаях политической конъюнктурой.

Выдвинутые лингвистами положения касательно природы и специфических характеристик коммуникативного пространства нашли отражение и в трудах театральных деятелей. Так, «квазиреальность» коммуникативного пространства театрального дискурса обуславливается постановочным характером коммуникации. По выражению актера, режиссера и теоретика театра П.М. Ершова, театральная коммуникация представляет собой событие, возникающее на сцене «в форме жизни» (Ershov, 1959).

При этом коммуникативное сообщение коллективного адресанта в лице режиссера и актерской труппы является заранее продуманными отрепетированным, а словесная сторона подкреплена определенным набором жестов и соответствующей мимикой с целью максимального воздействия на адресата (зрительскую аудиторию). Коммуникация между адресантом и адресатом также не является «реальной», поскольку зритель проявляет себя как косвенный адресат коммуникативного процесса, в основном, как «молчащий наблюдатель» (в терминологии В.Н. Бабаяна (Babayan, 2008)).

Реакция адресата - оборотная сторона процесса театральной коммуникации в силу своей непредсказуемости.

Важность категорий пространства и времени (хронотопических характеристик коммуникативного пространства театрального дискурса), о которых говорилось выше, подчеркивает режиссер театра и кино В.И. Карп, который пишет о дискретности человеческого восприятия пространственных изображений, всегда осуществляемых во времени. Задача режиссера облегчить восприятие, обозначив в театральной постановке временные границы, в соответствии с которыми восприятие членится на отдельные ритмические такты (Karp, http://e-libra.ru/books/221334-osnovy-rezhissury.html).

Пространственно-временные характеристики действия отражены в авторских ремарках текста пьесы.

В свою очередь, общность коммуникативного пространства для всех участников дискурсивной практики - это, по мнению К.С. Станиславского, внедрение индивидуального видения в сознание партнера, которое происходит в процессе словесного воздействия. Актер в этом случае с помощью слов рисует картину «не для слуха, а для глаза». А публика, приходящая в театр, «незаметно для себя выходит из него обогащенная новыми мыслями, ощущениями и запросами благодаря духовному общению с ней авторов и артистов от 
сценических подмостков» (Stanislavskij, 1953: 165).

При структурировании театрального дискурса только зритель как один из участников коммуникации способен самостоятельно выбирать способ реагирования - реакцию на актерское исполнение. Такая реакция может зависеть от ценностно-эстетических представлений, знаний о реалиях, изображаемых на сцене, профессионализма театральной труппы, а также от общей эрудированности и культуры зрителя. Режиссер В.И. Карп пишет о том, что центральное место в системе оценки ситуации зрителем занимает способность человеческой психики к отождествлению (идентификации) (Karp, http://e-libra.ru/books/221334-osnovy-rezhissury.html).

Вместе с тем речевое поведение актера как участника театральной коммуникации обусловлено указаниями, которые дает ему режиссерпостановщик с опорой на авторские метатекстуальные вставки драматурга, представленные в непосредственном тексте пьесы. При выборе стратегий коммуникативного поведения актеров на сцене режиссер-постановщик руководствуется своими представлениями о той или иной коммуникативной ситуации, жизненным опытом, а также предполагаемой реакцией зрительного зала.

Необходимо отметить, что коммуникативное пространство театрального дискурса представляет собой речевую ситуацию, зону активного релевантного взаимодействия коммуникантов. Подобное взаимодействие обусловлено как лингвистическими характеристиками (непосредственное языковое наполнение ролей участников процесса коммуникации при учете выбора стратегий и тактик речевого поведения), так и экстралингвистическими факторами (хронотопические характеристики, взаимоотношения между коммуникантами, конвенции, регламентирующие речевое участие в процессе коммуникации каждого из ее участников правила). В рамках коммуникативного пространства театрального дискурса коммуникантами выступают автор пьесы, режиссер-постановщик, актеры, театральный коллектив и зрительская аудитория. Подобный список участников коммуникации обусловлен конвенциональностью театрального дискурса, которая также определяет место реализации театрального дискурса - пространство театра, разделенное на театральные подмостки и зрительный зал, и существование коммуникативных правил, определяющих поведение актеров на сцене и зрителей в зале.

Коммуникативное пространство театрального дискурса квазиреально в силу постановочного характера коммуникации. Информационное сообщение, получаемое и трансформируемое зрительской аудиторией, всегда заранее продумано и отрепетировано. На основании знаний о коммуникативном пространстве как таковом и пространстве театрального дискурса построим модель коммуникативного пространства театрального дискурса.

Театральная коммуникация, осуществляемая театральным коллективом и зрителем в рамках коммуникативного пространства, представляет собой типовой «коммуникативный акт»- взаимодействие, шаги коммуникантов навстречу друг другу (Klyuev, 2002: 14). Однако в рамках театральной коммуникации имеет место вербальная «однонаправленность», поскольку за непосредственную реализацию коммуникации несет ответственность именно театральная труппа. Зрителю же достается, в основном, молчаливая роль.

В то же время, театральная коммуникация представляет собой, в терминологии Е.В. Клюева, ожидаемый коммуникативный акт, объявленный 
адресантом в рамках специфических эпитекстовых жанров (например, в афише, театральной программе, анонсах, рецензиях и т.п.). Как подчеркивает ученый, данный тип коммуникативного акта относится к разряду тех, «уклониться от которых можно только 'не явившись'» (Klyuev, 2002: 101). Спектакль, представляемый на театральной сцене, включен в репертуар театра и объявлен заранее, что отражено в театральных афишах и на сайтах театров. Зритель чаще всего осознанно выбирает спектакль, на который собирается пойти. Возможно, он даже знает содержание представления, прочитав предварительно текст пьесы, краткое содержание, рецензии критиков или отзывы зрителей, уже посмотревших этот спектакль.

Определив выше, что представляет собой коммуникативное пространство театрального дискурса, а также выделив его основные аспекты, попытаемся построить модель коммуникативного пространства театрального дискурса. Непосредственно термин «модель» определяется, как «исследовательский конструкт реальности» и представляет собой «рабочий инструмент для изучения сущности рассматриваемого явления» (Karasik, 2013: $6)$.

Модель коммуникативного пространства театрального дискурса сконструирована и представлена ниже.

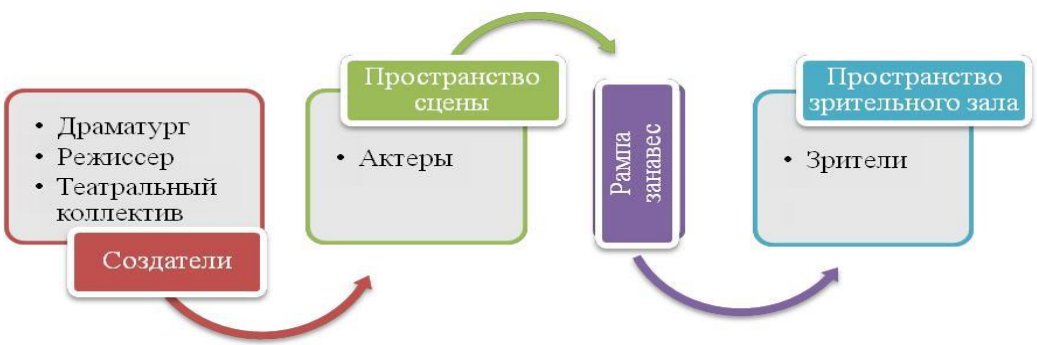

Рис. 1.Модель коммуникативного пространства театрального дискурса

Очевидно, что совокупное театральное пространство разделено на две части - пространство зрительного зала и пространство сцены. Рампа является «постоянной» границей, разделяющей эти пространства, а театральный занавес - элемент «одежды» театральной сцены - отделяет пространство сцены от пространства зрительного зала вплоть до начала представления.

Согласно утверждению М.Б. Ямпольского, театральный занавес служит символом «дистанцирования» - отдаления зрительской аудитории от событий, происходящих на сцене. Дистанцирование способствует удовлетворению любопытства со стороны наблюдателей (зрителей) по отношению к происходящему на театральной сцене. Приоткрывающийся театральный занавес является символом тайны, а зрители, пришедшие на представление, становятся посвященными в нее. Магия заканчивается, когда спектакль подходит к концу и занавес снова опускается (Yampol'skij, 2012: 121).

В то же время, согласно представленной модели, театральный дискурс воплощает совокупность релевантных коммуникативных пространств участников: драматурга, режиссера-постановщика, актеров на сцене, зрителей в зале и др. Однако эти пространства объединяются в пространство сцены и пространство зрительного зала, при взаимодействии которых осуществляется 
коммуникация.

Хотя театр представляет собой коллективное искусство, крайне важна роль режиссера-постановщика как модератора процесса театральной коммуникации. Под модерацией понимается «техника организации интерактивного общения, благодаря которой групповая работа становится более целенаправленной и структурированной» (Petrov, 2005: 9). Изучение вопросов модерации групповой работы особенно актуально в контексте обеспечения качества профессиональной деятельности актеров, композиторов, декораторов и других театральных работников, а также в контексте подготовки представления, предлагаемого на суд зрителей.

Подобная коллегиальность и сплоченность отражена в предлагаемой модели коммуникативного пространства в театральном дискурсе.

Инициируя театральную коммуникацию, режиссер отвечает за успешность ее реализации на всем протяжении спектакля. К такому выводу можно прийти, проанализировав труды режиссеров, применяя принцип нарративности (Radchenko, 1998: 125). Применяя данный принцип, можно опираться на персонифицированные идеи, гипотезы и термины, выдвигаемые в частности, специалистами в сфере театра.

Для формирования экстралингвистического контекста при рассмотрении коммуникативного пространства театрального дискурса необходимо создание эмпирической базы. В настоящем исследовании были использованы работы режиссеров К.С. Станиславского, В.И. НемировичаДанченко, В.И. Карпа и др. как контекст реализации театральной коммуникации, а также публикации в официальной прессе (интервью с М.Г. Розовским) как информационный ресурс, что позволяет вычленить основные дискурсивные практики театрального сообщества в рамках театральной (профессиональной) коммуникации.

Так, режиссер театра и кино Г.М. Козинцев утверждал, что профессия режиссера характеризуется необходимостью творческих отношений с множеством людей - писателями, актерами, операторами, сценаристами и т.д. Режиссер призван вызывать «у каждого из них феномен творчества (стимулируемой фантазии, собственной активной деятельности, собственного ряда ассоциаций)» (Цит. по: Karp, http://e-libra.ru/books/221334-osnovyrezhissury.html). Впоследствии режиссер-постановщик синтезирует в спектакле деятельность всех участников театральной коммуникации, находящихся в пространстве сцены (см. рис. 1).

По словам режиссера В.И. Карпа, представитель этой профессии «выступает в качестве дирижера оркестра, который состоит из деятелей разных видов искусств» (Karp, 1968: 3).

В то же время драматурги театральный деятель В.И. НемировичДанченко представлял режиссера как «трехликое существо» (NemirovichDanchenko, 2003: 256), воплощающего в себе качества

1) толкователя и наставника, помогающего актеру реализовать себя и воплотить персонаж на сцене;

2) зеркала, где находят свое отражение индивидуальные особенности каждого из актеров; и, наконец,

3) организатора всего спектакля, отвечающего за его целостность. Только последняя ипостась эксплицитна для зрителя, поскольку проявляется во всем рисунке спектакля. Первые две функции остаются явными исключительно для актера. 
Останавливаясь на взаимоотношениях режиссера и драматурга, Н.Н. Евреинов подчеркивает, что режиссер представляет собой детального толкователя авторского замысла посредством корреляции печатного текста с живым языком жестов и мимики (Evreinov, 1911). Так, в интервью авторитетный современный режиссер М.Г. Розовский, цитируя П. Брука, называет подобную работу над драматургическим произведением «предчувствием театра» (Цит. по: OTR, http://www.otronline.ru/programmi/programmparts_10707.html).

В то же время режиссер первым разрабатывает эскиз декораций, чтобы в последствии театральный художник и сценограф могли воплотить в жизнь то, что наиболее соответствует характеру пьесы. Хореография и особенности передвижения актеров по сцене также нуждаются в режиссерской постановке.

Режиссер - композитор, сочиняющий мелодию сценической речи, ее общую музыку, ансамбль, темп, паузы. Наконец, режиссер - это преподаватель искусства игры актерам. Следовательно, одним из важнейших компонентов деятельности режиссера является помощь и наставление актерскому составу (Там же).

Режиссер воплощает замысел спектакля через актера. По мнению В.И. Карпа, «актер находится в самом центре сценических событий. Он -живая связь между текстом автора, сценическим решением режиссера и восприятием зрителя» (Karp, http://e-libra.ru/books/221334-osnovy-rezhissury.html).

Таким образом, мастерство актера как участника коммуникации со зрителем требует особого таланта, воображения, умственной памяти и памяти тела, темперамента, а также умения отбирать и обобщать жизненный материал.

Применяя термин, введенный К.С. Станиславским, все действия актера на сцене, все мастерство направлено на решение сверхзадачи - основной цели, которой подчинены все задачи произведения (Stanislavskij, 1953). В этой связи неслучайно актерству приписывается характеристика зеркальности, поскольку «актер превращает свое тело в увеличительное стекло истины» (Yampol'skij, 2012: 41).

Пространство зрительного зала, представленное в нижней части модели театральной коммуникации (Рис. 1), заполняет зрительская аудитория, на которую оказывается сильнейшее эмоциональное, эстетическое, психологическое и ценностное воздействие со стороны актеров, играющих на театральной сцене. Имеет место то, что М.Б. Ямпольский метко обозначил как «навязывание зрителю зрения» (Yampol'skij, 2012: 41).

С точки зрения В.Н. Бабаяна (Babayan, 2008: 93), театральная аудитория представляет собой один из типов молчащего наблюдателя в силу ярко выраженной условности дискурса - содержание реплик заранее известно актерам, а в некоторых случаях известно и зрителям.

Зритель выступает как множественный наблюдатель за происходящим на сцене. Важно отметить, что зрительская аудитория не является однородной, поскольку восприятие воплощенного на театральной сцене действия может варьироваться в зависимости от различных факторов. В частности, возраст зрителей является важным демографическим фактором, обуславливающим особенности зрительского восприятия и реакции. Например, существуют детские спектакли, направленные на развитие воображения, эрудиции, вкуса, нравственных душевных качеств ребенка. Иначе говоря, особенности зрительского восприятия того, что происходит на сцене, во многом обусловлены жизненной стратегией конкретного зрителя. Согласно Л.А. 
Говердовскому, жизненное пространство индивида, как и его система ценностных идеалов, сконструированы на основе его жизненной стратегии, характерные особенности которой определяются, с одной стороны, социокультурными параметрами общества, а с другой стороны, социальнопсихологическими характеристиками самого индивида (Goverdovskij, 2011). При наличии сформированного ценностного идеала можно расставлять приоритеты целей и средств их достижения, что, в свою очередь, превращает жизненную стратегию поведения (зрителя в данном случае) в программу деятельности.

Следовательно, успех или неуспех театрального представления зависит не только от профессионализма и одаренности драматурга, режиссерапостановщика и актеров, но и от различных имплицитных факторов, влияющих на зрительскую аудиторию. Следует принять в расчет такой фактор, как профессионализм театральной труппы, убедительность актерской игры, доступность происходящего для зрительского восприятия. Умение привлечь внимание аудитории к представлению, возбудить интерес и спровоцировать положительную реакцию близко по характеру к программированию личностного поведения. Театральная труппа выполняет ряд операций конкретных действий, обусловленных конечной целью: разрушение «барьера невнимания или барьера неконтактности» (Vojskunskij, 2010: 18). Подобные действия имеют фасцинирующий характер. Изначально термин фасцинация (англ. fascination - очарование) был впервые употреблен отечественным лингвистом и этнографом Ю.В. Кнорозовым и определялся как «действие сигнала, при котором ранее принятая информация полностью или частично стирается» (Knorozov, 2010б: 4). Исходное информационное сообщение характеризуется не только аттрактивностью, но и индуцированностью фасцинации в сознании адресата. Согласно утверждению В.И. Карасика, фасцинативное восприятие информации предполагает «эмоциональное переживание, эмпатическое слияние», а также ощущение особой значимости информационного сообщения для личности (Karasik, 2013: 10). Однако, основываясь на этимологии термина, можно определить фасцинацию как волшебство, чары, магический эффект (Zheltuhina, 2003). Именно подобная «магическая» сущность феномена обуславливает использование фасцинации в театрализованных представлениях с целью формирования у зрительской аудитории соответствующего эмоционального состояния. Как подчеркивает Ю.В. Кнорозов, «искусство собственно и начинается с семантической фасцинации, с того момента, когда человек сделал великое открытие возможности выдумки» (Knorozov, 2010б: 4). Однако, несмотря на широкое использование феномена фасцинации в области искусства, весь процесс театральной коммуникации не может быть определен как исключительно фасцинативный. Одной из задач искусств является создание образа персонажа или ситуации, для чего необходимо выбрать фокусный момент, раскрывающий соответствующую характеристику. Удачный выбор фокусного момента способствует возникновению адекватного представления о персонаже или ситуации, разыгрываемой на театральной сцене, даже если фасцинирующие приемы не применялись. Согласимся с Ю.В. Кнорозовым в том, что «в искусстве используется фасцинация, но искусство не сводится к технике фасцинации» (Knorozov, 2010a: 17).

\section{Выводы}


1. Коммуникативное пространство театрального дискурса понимается как двусторонний процесс, в рамках которого адресант является передатчиком информационного сообщения, в то время как адресат воспринимает и перерабатывает информацию. Подобное коммуникативное пространство обладает определенными лингвистическими и экстралингвистическими характеристиками.

2. В рамках коммуникативного пространства театрального дискурса взаимодействуют два пространства: сцены и зрительного зала. Пространство сцены включает в себя микропространства драматурга, режиссерапостановщика, театральной труппы и т.д. Центральное место занимает фигура режиссера-постановщика как организатора и модератора коммуникативного акта. Пространство зрительного зала, в свою очередь, вмещает микропространство каждого из зрителей. Зритель представляет собой множественного наблюдателя за происходящим на театральной сцене. Среди зрителей выделяются следующие группы: зритель-обыватель, зрительпоклонник, зритель-профессионал (автор пьесы, критики).

3. Коммуникативное пространство театрального дискурса предполагает взаимодействие между многокомпонентным адресантом и адресатом. Адресант (драматург) передает сообщение прямому адресатуретранслятору первого плана (режиссер-постановщик) для последующей интерпретации. Следующей инстанцией становится терциарный адресат второго плана - театральная труппа. Наконец, зритель представляет собой квазиадресата. Он является заключительной точкой процесса театральной коммуникации, без которой реализация данного коммуникативного процесса невозможна. Адресат и адресант в рамках коммуникативного пространства театрального дискурса представляют собой дискурсивное экспертное сообщество, состоящее из драматурга и театрального коллектива под руководством режиссера-постановщика, а также зрителя-наблюдателя.

4. Театральный дискурс реализуется согласно определенному коммуникативному кодексу, регламентирующему место действия (театр), наличие конкретных участников (драматург, режиссер-постановщик, театральный коллектив, зрители), а также их коммуникативные стратегии, которые определены до начала процесса коммуникации.

\section{Заключение}

Таким образом, подводя итог сказанному, отметим, что модель коммуникативного пространства театрального дискурса выявляет взаимодействие двух коммуникативных макропространств: пространства сцены и пространства зрительного зала. Зритель, будучи массовым адресатом, наблюдает за происходящим на театральной сцене. Работа театрального коллектива не может быть реализована при отсутствии зрителей (актеры не будут играть пьесу на сцене перед пустым залом). Следовательно, применяя выражение П.М. Ершова, театральный коллектив «нуждается» в зрителях (Ershov, 1959), которые выступают в роли непосредственного адресата театрального дискурса.

Настоящее исследование осуществлено в современной парадигме научного знания, базирующегося на позициях антропоцентризма. Оно является звеном в изучении авторского фактора в театральном коммуникативном пространстве, поскольку драматург как адресант театрального текста использует метатекстуальные вставки, выраженные соответствующими 
языковыми средствами, как инструментарий ориентирования для адресатов разного уровня. Теоретическое осмысление авторского метатекста как ориентирующей системы дает возможность дальнейшей разработки проблемы графических особенностей театрального текста, составляющего печатную основу для театральной адаптации драматургических произведений. Осмысление театрального дискурса как институционального образования, а также жанрового своеобразия авторского метатекста как одной из его составляющих, позволяет обратиться к дальнейшей разработке проблемы коммуникативно-прагматических установок, определяющих в значительной мере успех коммуникации в театральной сфере. Оценка результатов, полученных в ходе работы, представляется важной для дальнейшей разработки таких кардинальных проблем теоретической лингвистики, как речевое воздействие, оптимизация социальной функции языка. Данное исследование коммуникативного пространства театра является шагом на пути дальнейших исследований театрального дискурса как перспективного объекта лингвистического анализа.

\section{Bibliographic references}

AVSEENKO, YA.L. - DUHVALOVA, M.P. - NAUMOVA, M.E. 2001. Formirovanie kommunikativnogo prostranstva publichnoj persony // Sovremennye psihotekhnologii v obrazovanii, biznese, politike: Mat-ly mezhdunar. nauch.-prakt. konf. Moskva, 28 fevr.-2 marta 2001 g. M.: GP CRP Moskva - SPb. pp. 258-260.

BABAYAN, V.N. 2008. Dialog v triade s molchashchim nablyudatelem: monografiya. YAroslavl': RIC MUBiNT. ISBN 5930021821, 9785930021820.

BIROVA, J. 2014. Lesson Effectiveness, Strong and Weak Sides of the Initial Implementation of the Integrated Language Approach. In: Komunikacie. Vol. 16, no. 3., pp. 41-46. ISSN 1335-4205.

BORBOT'KO, L.A. 2015. Avtorskij metatekst kak orientiruyushchaya sistema $\mathrm{v}$ kommunikativnom prostranstve teatral'nogo diskursa: dissertaciya ... kandidata filologicheskih nauk: 10.02.19. Moskva: MGPU.

BORBOT'KO, L.A. 2017. Teatral'nyj diskurs: chelovek v kommunikativnom prostranstve. In: CHelovek i ego diskurs - 5: teatr - massmedia - politika - biznes: kollektivnaya monografiya / otv. red. M.R. ZHeltuhina; VGSPU; IYA RAN. M. Volgograd: IYA RAN; PrinTerra-Dizajn. Pp. 11-44. ISBN 978-5-98424-207-3.

CHARFAOUI, E. - MITYAGINA, V. A.: Formirovanije terminosystemy menedžment v koordinatach nemeckogo, slovackogo i russkogo jazykov. In: Jazykovedné, literárnovedné a didaktické kolokvium 24. Bratislava: Z-F Lingua, 2014. pp. 91-99, 203-212 ISBN 978-80-89328-96-3.

ERSHOV, P.M. 1959. Tekhnologiya akterskogo iskusstva: ucheb. posobie. M.: VTO. ISBN 5-88296-003-7, 5-88296-002-9.

EVREINOV, N.N. 1911. Hudozhniki v teatre V.F. Komissarzhevskoj // Sbornik Pamyati Very Fedorovny Komissarzhevskoj. SPb.: Peredvizhnoj teatr P. P. Gajdeburova i N.F. Skarskoj.

FILATOVA N.A. - FILATOVA A.A. - SAVELIEVA, E.B. 2016. Author's space nominative localizers in Andreï Makine's novel "Le Testament français". In: Russian Linguistic Bulletin. 2016. №2 (6). pp. 83-84. DOI: 10.18454/RULB.6.12

GASPAROV, B.M. 1996. YAzyk. Pamyat. Obraz. Lingvistika yazykovogo sushchestvovaniya: ucheb. posobie. M.: Novoe literaturnoe sobranie. ISSN-08696363 ISBN 5-86793-020-3. 
GOVERDOVSKIJ, L.A. 2011. Metodologiya issledovaniya zhiznennogo prostranstva lichnosti: avtoref. dis. ... kand. filos. nauk: 09.00.13. Volgograd.

HYOJZINGA, J. 1997. Homo Ludens; Stat'i po istorii kul'tury. / Per., sost. i vstup. st. D.V. Sil'vestrova; Komment. D. EH. Haritonovicha. M.: Progress - Tradiciya. ISBN 978-5-91181-590-5.

KARASIK, V.I. 2013. Yazykovaya matrica kul'tury. M.: Gnozis. ISBN 978-5-94244043-5.

KARP, V.I. Osnovy rezhissury. URL: http://e-libra.ru/books/221334-osnovyrezhissury.html, svobodnyj.

KLYUEV, E.V. 2002. Rechevaya kommunikaciya. M.: Ripol Klassik. ISBN 5-79051349-2.

KNOROZOV, YU.V. 2010a. K voprosu o klassifikacii signalizacii. Fascinaciya. Kommunikaciya. Obshchenie: sbornik nauch.-popul. tekstov o fascinacii. M.: Avtorskaya akademiya fascinologii V. Sokovnina. pp. 8-18.

KNOROZOV, YU.V. 2010b. Ob izuchenii fascinacii .Fascinaciya. Kommunikaciya. Obshchenie: sbornik nauch.-popul. tekstov o fascinacii. M.: Avtorskaya akademiya fascinologii V. Sokovnina. P. 4.

KRALIK, R. - TINLEY, S. J. 2017. Kierkegaard's ethics as an answer to human alienation in technocratic society. In: Komunikacie, vol. 19, n. 1, pp. 25-29. ISSN 1335-4205.

KRALOVA, Z. - KUBALÍKOVÁ, A. 2013. Partnership around Continuous Training of Teachers. In: New Educational Review, Vol. 32 N. 2, pp. 275-276. ISSN 17326729.

MITYAGINA, V.A. 2014. Perevod v formirovanii turisticheskogo internet-diskursa. In: Media- i mezhkulturnaya kommunikatsiya $\mathrm{v}$ evropeyskom kontekste: materialy Mezhdunarodnoy nauchno-prakticheskoy konferentsii. Stavropol, Izd-vo SeveroKavkazskogo federalnogo un-ta, pp. 346-348.

NEMIROVICH-DANCHENKO, V.I. 2003. Iz proshlogo. Moj 20-j vek M.: Kukushka. ISBN 5-98262-003-3.

Obshchestvennoe televidenie Rossii. URL: http://www.otronline.ru/programmi/programmparts_10707.html, svobodnyj. (OTR)

PAVLIKOVA, M. 2017. Consciousness of anxiety in literary work of Don DeLillo. In: In: XLinguae, vol. 10, n. 1, pp. 62-69. ISSN 1337-8384.

PETROV, A.V. 2005. Diskussiya i prinyatie reshenij v gruppe: tekhnologiya moderacii. SPb.: Izd-vo «Rech'». ISBN 5-9268-0329-2.

PISONOVA, M. 2016. Philosophical Explication of Requirements on the Process of Education - Novelty or Relic? In: XLinguae, vol. 9, n. 1, pp. 83-90. ISSN 13378384.

PLOTNIKOVA, S.N. 2008. Yazykovoe, diskursivnoe i kommunikativnoe prostranstvo. In: Vestnik IGLU: sb. nauch. statej, № 1, pp. 131-136. ISSN 1997-0730

POCHEPCOV, G.G. 2001. Teoriya kommunikacii: ucheb. posobie. M.: Vakler. ISBN 5-87983-101-9, 966-543-062-9, 966-543-048-3.

RADCHENKO, O.A. 1998. O narrativnom napravlenii v sovremennoj lingvoistoriografii // Teoriya i metodika prepodavaniya romano-germanskih yazykov v sovremennom vuze. Arakinskie chteniya 1998 g.: Sb. nauch. trudov. M.: MGPU. pp. 124-130.

SAVELIEVA, E. A. 2012. Gide en Russie. Actualités d'André Gide. In: Actes du colloque international organisé au Palais Neptune de Toulon et à la villa Noailles à Hyères les 10-12 mars 2011. Paris: Honoré Champion Editeur. pp. 139-143.

SAVELYEVA, E.B. - LINEVA, E.A. The author in fiction litterature communication. In: Xlinguae. Vol. 8 N. 3, June 2015, pp. 76-90. ISSN 1337-8384. 
STANISLAVSKIJ, K.S. 1953. Stat'i. Rechi. Besedy. Pis'ma. M.: Iskusstvo.

VALCO, M. - KRALIK, R. - BARRETT, L. 2015. Moral implications of Augustine's philosophical and spiritual journey in his confessiones. In: Komunikacie, vol. 17, n. 2, pp. 103-108. ISSN 1335-4205.

VALCOVA, K. - PAVLIKOVA, M. - ROUBALOVA, M. 2016. Religious existentialism as a countermeasure to moralistic therapeutic deism. In: Komunikacie, vol. 18, n. 3, pp. 98-104. ISSN 1335-4205.

VIKULOVA, L.G. - SEREBRENNIKOVA E.F. 2014. Struktury modelirovaniya cennostnyh orientirov diskursa social'noj real'nosti $\mathrm{v}$ massmedijnom kommunikativnom prostranstve // Vestnik MGPU. Ser. «Filologiya. Teoriya yazyka. Yazykovoe obrazovanie», № 2 (14), pp. 55-63. ISSN 2076-913X.

VOJSKUNSKIJ, A. 2010. Ya govoryu, my govorim... Fascinaciya. Kommunikaciya. Obshchenie: sbornik nauch.-popul. tekstov o fascinacii. M.: Avtorskaya akademiya fascinologii V. Sokovnina. Pp. 18-28.

VORONCOVA, T.A. 2009. Kommunikativnoe prostranstvo v lingvopragmaticheskoj paradigme // Vestnik Udmurtskogo universiteta. Ser. Istoriya i filologiya, № 1, pp. 11-17. eISSN 2413-2454.

YAMPOL'SKIJ, M. 2012. Nablyudatel'. Ocherki istorii videniya. SPb.: Masterskaya SEANS. ISBN 978-5-905669-06-4.

ZHELTUHINA, M.R. 2003. Tropologicheskaya suggestivnost' massmedial'nogo diskursa: o specifike rechevogo vozdejstviya tropov v yazyke SMI. Moskva - Volgograd: IYA RAN, VF MUPK. ISBN 5-88234-568-5.

ZHELTUKHINA, M.R. - KRASAVSKY, N.A. - PONOMARENKO, E.B. - ALESHCHANOVA, I.V. - PAVLOV, P.V. 2016. Political Facebook Posts Using Ideological Symbols for Media Image Designing of Russia as Enemy. International Journal of Environmental and Science Education, 11(18), 12005-12013. eISSN 1306-3065.

ZHELTUKHINA, M.R. - SLYSHKIN, G.G. - PONOMARENKO, E.B. - BUSYGINA, M.V. - OMELCHENKO, A.V. 2016. Role of Media Rumors in the Modern Society. International Journal of Environmental and Science Education, 11(17), 10581-10589. eISSN 1306-3065.

ZHELTUKHINA, M.R. - VIKULOVA, L.G. - SEREBRENNIKOVA, E.F. GERASIMOVA, S.A. - BORBOTKO, L.A. 2016. Identity as an Element of Human and Language Universes: Axiological Aspect. International Journal of Environmental and Science Education, 11(17), 10413-10422. eISSN 1306-3065.

ZHELTUKHINA, M.R. - VIKULOVA, L.G. - SLYSHKIN, G.G. - VASILEVA, E.G. 2016. Naming as Instrument of Strengthening of the Dynastic Power in the early middle Ages (France, England, Vth - XIth Centuries). International Journal of Environmental and Science Education, 11(14), 7195-7205. eISSN 1306-3065.

ZHELTUKHINA, M.R. - ZINKOVSKAYA, A.V. - KATERMINA, V.V. SHERSHNEVA, N.B. 2016. Dialogue as a Constituent Resource for Dramatic Discourse: Language, Person and Culture. International Journal of Environmental and Science Education, 11(15), 7408-7420. eISSN 1306-3065.

Words: 4835

Characters: 43303 (24,05 standard pages)

Prof. Marina Rostislavovna Zheltukhina, DrSc.

Institute for Foreign Languages 
Volgograd State Socio-Pedagogical University

Lenin Prospect 27

400066 Volgograd

Russia

zzmr@mail.ru

Prof. Larissa Georgievna Vikulova, DrSc.

Institute for Foreign Languages

Moscow City Teacher Training University

5 b Maly Kazenny per.

105064 Moscow

Russia

vikulovalg@mail.ru

Assoc. Prof. Svetlana Vladislavovna Mikhaylova, PhD.

Institute for Foreign Languages

Moscow City Teacher Training University

5 b Maly Kazenny per.

105064 Moscow

Russia

jevouslis@mail.ru

Assoc. Prof. Liudmila Alexandrovna Borbotko, PhD.

Institute for Foreign Languages

Moscow City Teacher Training University

5 b Maly Kazenny per.

105064 Moscow

Russia

ludmilaborbotko@gmail.com

prof. Dr. Alfiya R. Masalimova

Institute of Psychology and Education

Kazan (Volga region) Federal University Kazan

Russia

alfkazan@mail.ru 